脹や波動を触れ臨床的に強く囊胞を示唆した症例は51 側であり，エコーグラムでCystic patternを示したも のは48側 (94.1\%) であった。顂部腫脹や波動を触れ ず臨床的に䇥胞を否定した症例は31側であり，エコー グラムで Cystic pattern を示したものは21側(67.7\%) であった。 4) CT を撮影した10例すべてに雴胞を認め たが䜖胞数に関して手術と一致しなかったもの 5 例で あった.5）単房性症例28例において，エコーグラムと 断層撮影で賈胞の大きさと深さを測定し, 一致率を検 討した結果，一致した症例は16例 (57.1\%) であった。 囊胞の深さのみ一致した症例は 2 例, 囊胞の大きさの み一致した症例は 5 例で, ともに一致しなかった症例 は 5 例であった。

結語 超音波 A モード法による術後性上颚囊胞の
診断は, 露胞の有無については断層撮影に比べゃや少 るが $84.1 \%$ と診断率は高く有用であると思われた。産 胞数や位置, 大きさについてはエコーグラムは断層撮 影に比べ診断的精度が悪く, それは probe をあてる位 置の問題や賈胞の存在部位によるものと考えられた。 現在診断的価值をより高める方法として probeの位 置や方向など規格化して検討している. 術後性上類襄 胞の診断にはエコーグラムだけでは困難であり, 従来 からの X 線撮影, CT 検査, 試験穿刺など総合的に診 断しなければならないと思われた。質問 行木英 生(国立栃木)。超音波検査法で診断率のあがらない賈 胞の局在部位について。. 応答 ご指摘の通り，囊 胞の部位により出にくい場合がある。特に上顎洞外側, 下壁側, 後方に出現率が悪い.

\title{
296. 術後性上顎囊胞の画像診断
}

\author{
塩野博己・田久保正道・北原伸郎・飯沼壽孝（東大分院）小山和行（東大・放射線科）
}

目的 術後性上䪽襄胞の画像診断法として, X 線 CT と超音波検査法 (A，Bモード) に注目し, これら の画像診断の結果と手術所見とを比較検討, さらに超 音波検査の有用性と限界について報告した。

対象 昭和61年 1 月より昭和63年 9 月までに, 全例 にX 線 CT, 超音波検查を行い,一部 MRI 検査を加え 診断し手術を行った術後性上顎囊胞48症例, 54側であ る.

万法 X 線 CT は東芝 TCT60A60 で軟部組織用, 骨組織用条件を用いた。 スキャン方向は水平方向であ る. A モードはリオン UM-01 (径 $13 \mathrm{~mm}, 3.5 \mathrm{MHz}$ ),

房数および䨩胞の位置関係

\begin{tabular}{|c|c|c|c|c|c|}
\hline & \multicolumn{2}{|l|}{ 房 } & \multicolumn{2}{|c|}{ 位置関係 } \\
\hline & & 単房 & 多房 & 単房 & 多房 \\
\hline \multicolumn{2}{|c|}{ 手術所見(基準) } & 30 & 24 & 30 & 24 \\
\hline \multirow{2}{*}{\begin{tabular}{|l} 
正 \\
解 \\
例
\end{tabular}} & $\mathbf{X}$ 線 C T & 27 & 21 & 26 & 18 \\
\hline & Bモード & 23 & 9 & 21 & 9 \\
\hline
\end{tabular}

不完全隔壁と骨破壊（境界壁）

\begin{tabular}{|c|c|c|c|c|}
\hline & \multirow{2}{*}{ 不完全隔壁 } & \multicolumn{2}{|c|}{ 骨 破 壊 } \\
\hline & & & 後壁 & 眼浻底 \\
\hline \multicolumn{2}{|c|}{ 手術所見 } & 11 & 14 & 7 \\
\hline \multirow{2}{*}{$\begin{array}{l}\text { 正 } \\
\text { 解 } \\
\text { 例 }\end{array}$} & $\begin{array}{c}\mathbf{X} \text { 線 C T } \\
\text { (水平断) }\end{array}$ & 6 & 7 & 2 \\
\hline & $\begin{array}{c}\text { Bモード } \\
\left(\begin{array}{c}\text { 水平断 } \\
\text { 状断 }\end{array}\right)\end{array}$ & 3 & 3 & 0 \\
\hline
\end{tabular}

B モードは東芝 SSA-90 (3. 75MHz, リニア型, セク 夕型探触子）を用いた。 スキャン方向は水平, 矢状方 向である.今回は A モードの結果は省略する.さらに 4 例に MRI 検査を行った。

結果 手術所見を基準とした. $\mathrm{X}$ 線 CT, B モードに よる囊胞の検出率は単房, 多房性を問わずそれぞれ $54 /$ 54側， 100\%，50/54側，93\%であった。虽胞数での一 致率は単房性ではそれぞれ $27 / 30$ 側, $90 \%, 23 / 30$ 側, $77 \%$, 多房性ではそれぞれ $21 / 24$ 側, 88\%, 9/24側, 38 \%であった。囊胞位置での一致率は単房性ではそれぞ れ26/30側, 87\%, 21/30側, 77\%, 多房性ではそれぞ

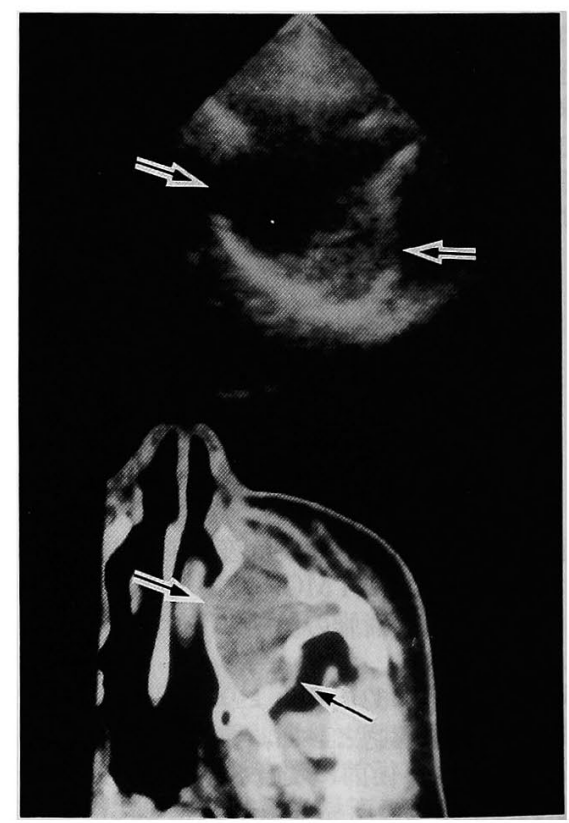


れ18/24側, 75\%，9/24側，38\%であった. 不完全隔壁 ての一致率はそれぞれ6/11側， $55 \% ， 3 / 11$ 側， $27 \%$, 骨破壊での一致率はそれぞれ $9 / 21$ 側，43\%，3/21側， 14\%であった(表).

症例の呈示 37歳, 男性, 左煩部腫脤。左上顎洞水 平断セク夕型超音波像 (写真上段) と, 水平断 $\mathrm{X}$ 線 CT （写真下段）とを比較した。洞内岋類円形, 低エコー, 均一て $4 \mathrm{~cm}$ の樑さで後壁エコー像を認め,下鼻道側壁 および後壁の膨隆と破壊（矢印）を認める全体型の単 房性霊胞エコー像である。
結論 1) 単房性㹕胞の房数と位置関係はX線 CT, B モードで良く診断できた。2）多房性䎬胞の房 数, 位置関係では, X 線 CT で単房性より診断は低下 した，Bモードではさらに低下した。前壁肥厚のある 下方, 後方, 眼窩下, 外側に存在する蕒胞が診断低下 について主因であった，3）不完全隔壁，骨破壊につい ては水平断 $\mathrm{X}$ 線 CT で診断が難しく, 冠状断を加える 必要がある。Bモードでも描出は困難であり，これは 機器扔よび超音波特性の限界による。

\section{7。頭蓋底の $\mathrm{X}$ 線 診断}

\section{一一視神経管の蝶形骨洞内隆起- -}

古橋靖夫 ・草刈 潤（筑波大）新井 峻（国立霞ヶ浦） 木内宗甫（筑波学園病院）

ヒトの副鼻腔は三次元的に複雑な構造をしており個 人差も大きい、そのなかでも蝶形骨调は最後部に位置 し頍蓋底に接しているために，その周囲は重要な構造 物に取りかこま机ている，特に視神経管は時として著 明な隆起として認められることがあり，診断，術前検 查として解剖学的な評価が重要となってくる。そこで 私達は副鼻腔 CT 像において軽位像を選択し，蝶形骨 洞の発達の程度と視神経管の洞内隆起 りの関係を検討 したので報告した。

方法 耳鼻咽喉科外来を受診し。鼻, 副鼻腔, 頭頸 部領域の疾患を疑われ CT を撮影した33例である。軸 位像は患者を仰臥位とし，ドイツ水平線に対して18度 頸部を伸展した体位を用いたが、これは視神経管に対 して水平面で撮影し，管全長を 1 枚の像として把握し ようとしたためである。蝶形骨洞の発達の程度を評価 するためにその内部の含気化を検討し，後方への段階 に応じて 4 つに分類した，すなわち I 型) 含気化がト ルコ鞍結節を越えないもの，II型）トルコ鞍結節を越 えているが，前床突起と後床突起の中間点を越えない もの，III型）中間点を越えるが後床突起を越えないも の, IV型) 後床突起を越えるもの. 視神経管の蝶形骨 洞内隆起の評価としては，3つに分類し，判定は最も 著明な隆起の認められた像で行った.1) 隆起の認めら れないもの，2）視神経管の直徍の $1 / 2$ 以下の隆起を認 めるもの,3）直径の1/2以上の隆起を認めるものとし，
2）を軽度隆起，3）を高度隆起とした。

結果 33例の蝶形骨洞像と66側の視神経管像が得ら れた。洞の発達をみるとI 型が 1 例 $(3 \%)$ ，II型が11 例 $(33 \%)$ ，III型が14例 $(42 \%) ， I V$ 型が 7 例 (22\%) であり，視神経管隆起については軽度隆起が19側 $(29$ $\%)$ ，高度隆起が16側 (24\%) であった。また視神経管 隆起の左右差は10例（30\%）にみられた。蝶形骨洞の 発達の程度と視神経管隆起の関係においては，I 型で は視神経管隆起の認められるものはなく，II型，III型 では軽度隆起がそれぞれ 5 側 $(8 \%) ， 10$ 側 (15\%) で あり，高度隆起はそれぞれ 2 側 $(3 \%) ， 6$ 側（9\%） であった，IV型では軽度隆起が 4 側 $(6 \%)$ ，高度隆起 が 8 側 (12\%) であり，このタイプのように蝶形骨洞 の発達の良好なものには，洞内視神経管骨壁が一部欠 損しているがごとき像を呈したのも認められ，今回の 検討のなかにも3 例 (5 側) に諗められた。このよう に蝶形骨洞，また洞内視神経走行には著しい個体差が 認められる場合があり，蝶形骨洞内に病変を有する疾 患の診断ないし術前検查においては，視神経管の走行 を十分に検討する必要があると考えられる。

質問 行木英生 (国立栃木)。視神経管の CT 撮影として, CT 断層面はドイツ水平面から何度ついているのか. 応答 通常の軸位像でなく，ドイツ水平線に対して18 度頸部を伸展した面での像である。この断面にて蝶形 骨洞の発達の程度も判定した。

\section{8．タウ・トランスフェリン検出による䯣液鼻漏の診断}

\section{長谷川 誠・横山和則・渡辺 勈（東医歯大）}

目的 トランスフェリンは生体内では分子量約 8 万 の栯タンパクで，鉄の運搬体として働いているが，電 気泳動により特異的に分けられるタウ・トランスフェ リンは䯣液にのみ認められ, 血液, 鼻汁, 淚液, 唾液
等には検出されないことが知られている.今回の発表 の目的は，髄液鼻漏の診断に際してのタウ・トランス フェリン検出法の有用性について述べることにある。

方法 (i）鼻汁採取法：頭をしばらく前方に傾ける 